\title{
Major Salivary Gland Cancer Pathologic TNM Finding v7
}

National Cancer Institute

\section{Source}

National Cancer Institute. Major Salivary Gland Cancer Pathologic TNM Finding v7. NCI

Thesaurus. Code C89119.

A pathologic finding about one or more characteristics of major salivary gland cancer, following the rules of the TNM AJCC v7 classification system. 